\title{
The 2014 credit-information amnesty regulations: What do they really entail?
}

Michelle Kelly-Louw

BIUr LLB LLM LLD, Dip Insolvency Law and Practice

Professor of Banking Law, College of Law, University of South Africa

\section{OPSOMMING}

Die 2014 Kreditinligting Amnestie Regulasies: Wat behels hulle regtig?

Op 1 April 2014 het regulasies ingetree wat behels dat sekere nadelige verbruikerskredietinligting en inligting aangaande volopbetaalde siviele vonnisse van alle kredietrekords van verbruikers wat gehou word deur alle geregistreerde kredietburos verwyder moet word. Die regulasies maak voorsiening vir 'n proses ten aansien van die eenmalige verwydering van sodanige inligting sowel as om inligting aangaande volopbetaalde vonnisse op 'n voortdurende basis te verwyder. Die Nasionale Krediet Wysingswet 19 van 2014 maak ook voorsiening vir die deurentydse verwydering van sodanige inligting. Alhoewel die regulasies redelik eenvoudig is, is daar tog 'n paar fasette wat onduidelikheid veroorsaak. Grotendeels het dit te make met die korrekte interpretasie van sekere woorde en uitdrukkings wat in party subregulasies gebruik word. Dit is byvoorbeeld onduidelik of die regulasies ook van toepassing kan wees op sekere regspersone. Daar is ook nie sekerheid oor welke inligting steeds in verbruikers se betalingsprofiel mag verskyn en hoe sodanige regulasies die betalingsprofiele beïnvloed nie. Die regulasies bepaal duidelik dat die inligting wat verwyder is van die kredietrekords van verbruikers ingevolge die regulasies nie deur kredietgewers gebruik mag word tydens die assessering of 'n verbruiker kwalifiseer vir enige krediet nie. Wat die regulasie egter nie bepaal nie is of sodanige kredietgewer sodanige inligting mag gebruik waar hy dit bekom het deur nie na 'n kredietburoverslag te kyk nie, maar deur sy eie interne rekords na te gaan, byvoorbeeld in die geval waar hy met 'n bestaande kliënt te doen het nie. Hierdie aspekte, sowel as 'n paar ander, word in diepte in hierdie artikel bestudeer. Die impak wat die regulasies op die verbruikerskrediet mark tot dusver gehad het, sowel as 'n paar voordele en nadele van die regulasies word ook kortweg bespreek.

\section{Introduction}

Comprehensive credit information, which provides details pertaining to credit ... already availed of by a borrower as well as his repayment track record, is critical for the smooth operations of the credit market. Lack of credit history is an important factor affecting the credit flow to relatively less creditworthy borrowers. In the absence of credit history, pricing of credit can be arbitrary, the perceived credit risk can be higher, and there can be adverse

How to cite: Kelly-Louw 'The 2014 credit-information amnesty regulations: What do they really entail?' 
selection and moral hazard. ${ }^{1}$

The credit information of a consumer held by a credit bureau is often used by a credit provider to determine the consumer's credit profile and to determine whether he has a good or bad debt repayment history before granting any credit to him. It is therefore critical that credit bureaux keep only accurate consumer credit information that truly reflects the credit profile and debt repayment history of the consumer. A credit bureau report plays a decisive role in assisting a credit provider to accurately assess the debt repayment history and creditworthiness of a prospective consumer. The moment the integrity of the credit information kept by a credit bureaux is questioned, credit providers will start relying on other factors (possibly to the detriment of consumers) to assess the creditworthiness of a prospective consumer. Without a proper credit profile and debt repayment history, a credit provider may decide to only grant credit to a prospective consumer, who it perceives as carrying a high-risk for defaulting, at a very high interest rate.

In terms of section 81(2) of the National Credit Act ${ }^{2}$ (NCA or the Act), a credit provider may generally only conclude a credit agreement with a prospective consumer or increase an amount approved in terms of an existing credit agreement ${ }^{3}$ after it has done a proper and reasonable assessment and concludes that the consumer will be able to satisfy all his obligations under all his credit agreements, including the prospective credit agreement. ${ }^{4}$ The compulsory assessment requires that a credit provider not only does an "affordability" (financial) assessment of the consumer, but also assesses the consumer's debt repayment history and also tests the consumer's general understanding of the risks, cost and obligations of the credit agreement. ${ }^{5}$ If a credit provider neglects to do an assessment or fails to conduct a proper assessment, such conduct may constitute reckless lending ${ }^{6}$ which has many adverse consequences for

1 Devnomics (Developmentnomics (Pty) Ltd) Literature review on the impact of the National Credit Act (NCA) has had on South Africa's credit market (2012) (available from http://www.ncr.org.za,accessed 2014-09-01) 117.

234 of 2005 (the NCA or simply the Act). In this article words in the singular also mean words in the plural and vice versa, and words in the masculine also mean words in the feminine and neuter.

3 Other than an increase in terms of $\mathrm{s} 119(4)$

4 Read with s 80(1).

5 Kelly-Louw 'A credit provider's complete defence against a consumer's allegation of reckless lending' 2014 SA Merc LJ 2425 \& 32. See also s 81 (2).

6 See, in particular, ss $80 \& 81$. For a discussion of reckless lending in terms of the NCA, see Boraine \& Van Heerden 'Some observations regarding reckless credit in terms of the National Credit Act 34 of 2005' 2010 THRHR 650; Van Heerden \& Boraine 'The Money or the box: Perspectives on reckless credit in terms of the National Credit Act 34 of 2005' 2011 De Jure 392; Vessio 'Beware the provider of reckless credit' 2009 TSAR 274 281; Renke 'Measures in South African consumer credit legislation aimed at the prevention of reckless lending and over-indebtedness: An overview against the background of recent developments in the European Union' 2011 THRHR 208; Kelly-Louw supra n 5; Kelly-Louw (with contributions by Stoop) 
the credit provider. ${ }^{7}$

Section $82(1)$ of the NCA originally ${ }^{8}$ allowed a credit provider to determine for itself the evaluative mechanisms or models and procedures to be used in meeting its assessment obligation under section 81 , provided that they resulted in a fair and objective assessment. ${ }^{9}$ This section had to be read with section 61(5) of the NCA which provides that a credit provider may determine for itself any scoring or other evaluative mechanism or model to be used in managing, underwriting and pricing credit risk, provided that any such mechanism or model is not based or structured upon a statistical or other analysis in which the basis of risk categorisation, differentiation or assessment is a ground of unfair discrimination prohibited in section 9(3) of the Constitution of the Republic of South Africa of 1996. Section 82(1) was subject to section 82(2)(a) which stipulated that the National Credit Regulator (NCR) ${ }^{10}$ could pre-approve the evaluative mechanisms, models and procedures to be used in terms of section 81 regarding proposed developmental credit agreements. Furthermore, section 82(2)(b) provided that the NCR could also publish guidelines proposing evaluative mechanisms, models and procedures, to be used in terms of section 81 , applicable to other credit agreements. Therefore, credit providers have generally based their credit assessments of consumers on the information available from their own records and also from credit reports obtained by credit bureaux. In the

Consumer Credit Regulation in South Africa (2012) (hereinafter Kelly-Louw Consumer Credit Regulation) par 12.2; Scholtz (ed) et al Guide to the National Credit Act (2008-; loose-leaf) par 11.4. For a discussion of the Affordability Assessment Regulations that came into force on 13 Ma 2015 (see Reg Gazette No 10382 in GG No 38557 of 2015-03-13) and how they influence the reckless lending provisions set out in the NCA; see Van Heerden 'Reckless credit: Developments regarding affordability assessment and the extended powers of the National Consumer Tribunal' (paper delivered at the 2015 Annual Banking Law Update held in Johannesburg on 28 May 2015) 219-255. For cases dealing with reckless lending, see, eg, SA Taxi Securitisation (Pty) Ltd $v$ Mbatha and Two Similar Cases 2011 (1) SA 310 (GSJ); Desert Star Trading 145 (Pty) Ltd $v$ No 11 Flamboyant Edleen CC 2011 (2) SA 266 (SCA); Standard Bank of South Africa Ltd v Kelly and Another (23427I 2010) 2011 (WCHC) 1 (2011-01-25); Standard Bank of South Africa Ltd $v$ Newman (27771/2010) 2011 (WCHC) 91 (2011-04-15); Horwood v FirstRand Bank Ltd (2010/36853) 2011 (GPJHC) 121 (2011-09-21); ABSA Bank v Coe Family Trust 2012 (3) SA 184 (WCC); and Mercantile Bank Limited v Hajat 2013 JOL 30499 (GSJ).

7 See ss $83 \& 84$. For a detailed discussion of what the consequences of reckless lending are and what the powers of a court are when it declares an agreement as constituting reckless credit, see Kelly-Louw Consumer Credit Regulation supra $\mathrm{n} 6$ at par 12.2.3; and Scholtz et al supra $\mathrm{n} 6$ at par 11.4.5. The National Credit Amendment Act 19 of 2014, which came into operation on 13 March 2015, amends s 83 of the NCA so that the power to declare a credit agreement reckless is also bestowed upon the National Consumer Tribunal. It also provides that the Tribunal has exactly the same authority as a court to make appropriate orders (ie, in terms of ss $83(2) \&$ 83(3)).

8 See s 82(1) in its original form.

9 See also Horwood $v$ FirstRand Bank supra $\mathrm{n} 6$ at par 5

10 Established in terms of $\mathrm{s} 12$ (hereinafter the NCR). 
past, the NCR, responsible for the regulation of the consumer-credit market and nearly all credit providers, could therefore publish nonbinding guidelines proposing evaluative mechanisms, models and procedures to be used to determine whether credit was being granted recklessly in relation to credit agreements generally (other than for developmental agreements). ${ }^{11}$ In September 2013, the NCR issued draft "Affordability Assessment Guidelines". ${ }^{12}$ The draft guidelines aimed to assist credit providers to conduct proper assessments of the consumers' affordability in credit applications and to combat consumer overindebtedness as well as reckless lending. However, the decision was later taken to rather amend the NCA, allowing for prescribed Affordability Regulations to be issued which would be applicable generally. The National Credit Amendment Act of $2014^{13}$ (Amendment Act) which came into operation on 13 March $2014^{14}$ amends section 82 of the NCA. The Amendment Act amends section 82 in that it now gives the Minister of Trade and Industry (Minister) the authority to issue "Affordabililty Assessment Regulations". The amendment provides that such regulations must be made by the Minister if it is recommended by the NCR. The amendment to section 82 does not take away a credit provider's right to determine for itself the evaluative mechanisms or models and procedures to be used in meeting its statutory assessment obligation as long as they are not "inconsistent with the affordability assessment regulations" issued and provided that they result in a fair and objective assessment. ${ }^{15}$ On 1 August 2014, a comprehensive set of draft regulations on various matters including the draft Affordability Assessment Regulations were published for public comment and on 13 March 2015 the final regulations on various matters (the 2015 Regulations), including the final Affordability Assessment Regulations came into operation. ${ }^{96}$ In terms of the Amendment Act and the Affordability Regulations credit providers now have to ensure that their evaluative/assessment mechanisms or models and procedures are compliant with the latest changes.

In order to improve and integrate the credit-information infrastructure, provisions dealing with consumer credit information and credit bureaux were included in the NCA. ${ }^{17}$ For instance, it is compulsory for all credit bureaux to register ${ }^{18}$ with the NCR and the NCA is prescriptive of the type of consumer credit information that credit

11 See s 82(2)(b) read with s 82(3), prior their deletion by the National Credit Amendment Act 19 of 2014

12 Available from http://www.ncr.org.za (accessed, 2014-08-01).

13 Act 19 of 2014 (hereinafter the Amendment Act).

14 Published in GG 37665 of 2014-05-19.

15 See s 82(2) of the NCA, as amended by the Amendment Act.

16 See GN R597 in Regulation Gazette 10242 in GG 37882 of 2014-08-01 and see National Credit Regulations including Affordability Assessment Regulations published in Regulation Gazette No 10382 in GG No 38557 of 2015-03-13.

17 See the Department of Trade and Industry Consumer Credit Law Reform: Policy Framework for Consumer Credit (2004) 31.

18 In terms of $\mathrm{s} 43$. 
bureaux may hold. ${ }^{19}$ Particular duties are also placed on credit bureaux in respect of consumer credit information obtained and retained by them. $^{20}$ The Regulations to the NCA even specify the maximum retention periods that a consumer's credit information (such as a civil court judgment obtained against a consumer, the sequestration date of an insolvent consumer's estate, or number of enquiries made on a consumer's record) may be displayed by a credit bureau. ${ }^{21}$ A credit bureau must also comply with certain prescribed standards when maintaining consumers' credit information. ${ }^{22}$

The whole idea behind the statutory regulation of credit bureaux and consumer credit information is to ensure that credit providers may rely on more accurate credit information when assessing the consumer's debt repayment history. ${ }^{23}$ Unfortunately, this noble idea may be undermined by the Department of Trade and Industry's (DTI's) latest and second credit-information amnesty.

Before the NCA, the consumer credit information held by the credit bureaux was generally unreliable, incomplete and incorrect. In order to correct this unfortunate situation, regulations were issued in terms of the NCA to provide for the removal of consumer credit information that met certain criteria and assisted with the verification and review of certain adverse and negative consumer credit information that was kept by the different credit bureaux in the past (the 2006 Amnesty Regulations). ${ }^{24}$ The 2006 Amnesty Regulations provided for a certain period, after the NCA came into operation, in which all credit bureaux had to verify, review and remove certain consumer credit information from their records. For example, a civil-court judgment for an amount of R50 000 or less which was listed on the consumer's credit record on or before 1 September 2006 and was satisfied (paid up) before 31 December 2007, had to be removed within three months of its payment date. Plus, any adverse information in respect of debt less than R500 reflected on a credit record as at 1 September 2006 had to be removed from the

19 Ss 70-73. S 70(1) provides a description of what consumer credit information exactly entails (see also the discussion in par 3 infra).

20 For a full discussion, see Kelly-Louw Consumer Credit Regulation supra $\mathrm{n} 6$ at par 6.4.

21 See eg, reg 17 published in GN R489 in GG 28864 of 2006-05-31, substituted by GN R1209 in GG 29442 of 2006-11-30 and amended by Regulation Gazette No 10382 in GG No 38557 of 2015-03-13 For a full discussion, see Kelly-Louw Consumer Credit Regulation supra n 6 at par 6.5: see also Damon and Another $v$ Nedcor Bank Ltd 2006 JDR 0827 (C). Some of the amendment made in the 2015 Regulations includes an amendment to reg 17(1) providing for some of the maximum retention periods that consumer credit information may be displayed to be shortened and some adverse information to no longer be displayed.

22 See eg, ss 70-73.

23 See Kelly-Louw 'The prevention and alleviation of consumer overindebtedness' 2008 SA Merc LJ 200 221-2; and Kelly-Louw LAWSA (eds Joubert \& Faris) 5 (2010) par 131.

24 Published in GN R1209 in GG 29442 of 2006-11-30 (for a full discussion of these regulations, see Scholtz et al supra $n 6$ at par 15.6). 
records kept by credit bureaux by 1 June 2007. Generally this amnesty was welcomed by the consumer-credit industry as it was a well-known fact that, in the past, the consumer-credit records kept by credit bureaux were in a dismal state, and many consumers were "blacklisted" without their knowledge and without an opportunity to challenge the correctness of the adverse information being reported to the credit bureaux. Consumers could also not easily access the credit information kept by credit bureaux and it was practically impossible for a consumer to have incorrect or adverse credit information corrected or removed. A consumer also did not have an automatic right to access or challenge his information and records kept by credit bureaux. In general, consumers only discovered that they had adverse credit records when they tried to apply for credit and their applications were declined because of it. ${ }^{25}$

What was initially thought to be a once-off provision of creditinformation amnesty, resulted in a second and much more encompassing amnesty. The DTI felt that as a limited number of consumers benefited from the first amnesty, due to the monetary caps and lack of consumer education accompanying it, a further amnesty was needed. On 26 February 2014, the Minister published the Removal of Adverse Consumer Credit Information and Information relating to Paid Up Judgments Regulations (the 2014 Amnesty Regulations). ${ }^{26}$ The 2014 Amnesty Regulations came into operation on 1 April 2014 and pertain to the once-off removal of certain adverse consumer credit information from the records of all consumers, irrespective of the type of credit agreement or amount of debt/credit involved, kept by all the credit bureaux as at 1 April 2014. The regulations also provide for the once-off and on-going removal of information relating to civil judgments of consumers where the consumers settled the capital amount. The Amendment Act also introduces a process whereby certain adverse consumer credit information and information regarding paid up judgments, may automatically be removed from the credit record of a consumer on an on-going basis. ${ }^{27}$

In this article, attention is given to the 2014 Amnesty Regulations and the recent amendments to the NCA providing for the on-going automatic removal of certain adverse consumer credit information and information regarding paid up judgments. Although the 2014 Amnesty Regulations and the amendments to the NCA are for most parts fairly straightforward, there are a few aspects which are confusing and that require a further discussion.

25 Kelly-Louw Consumer Credit Regulation supra n 6 at 169.

26 Published in GN R144 in GG 37386 of 2014-02-26. For a brief discussion of how this project came about and what some of the initial amnesty proposals were, see Kelly-Louw supra n 5 at 39-40; Ackotia 'A short-lived pardon under the credit amnesty' GhostDigest (2014-09-12) (available from http://www.ghostdigest.co.za, accessed 2014-04-09).

27 See s 71A of the NCA inserted by the Amendment Act. 


\section{The 2014 Credit-Information Amnesty Regulations}

\section{Reasons for the Amnesty and Number of Consumers Benefitting}

The removal of the adverse consumer credit information from the credit profile of a consumer in terms of the 2014 Amnesty Regulations, does not also entail the removal (write-off) of the consumer's duty to repay the debt which is affected by the regulations to the respective credit provider. $^{28}$ The 2014 Amnesty Regulations stress that a consumer remains liable for the repayment of any outstanding debt owned in terms of any credit agreement, irrespective of whether any adverse information concerning that specific debt was removed from a credit bureau $^{29}$ unless, of course, the debt prescribed or any other applicable law prohibits its repayment.

The NCR's motivation for removing the adverse credit information was that the removal would benefit the low - and middle - income group to access credit such as home loans, educational loans, increase employment opportunities and would be beneficial to those who could not afford fees for the rescission of judgment debts which had already been paid. ${ }^{30}$ According to the DTI, the main purpose of the 2014 Amnesty Regulations is to enable blacklisted consumers whose financial circumstances have changed since they could not pay their debt in the past to be able to access credit again. ${ }^{31}$ It is hoped that the removal of certain adverse credit information from the records of consumers will enable these consumers to obtain employment and rental housing opportunities that would not otherwise have been possible if they had remained blacklisted. ${ }^{32}$

On 27 February 2014, a day after the 2014 Amnesty Regulations were published, the Minister justified the reasons for granting this second amnesty as follow: ${ }^{33}$

28 Ackotia supra $\mathrm{n} 26$

29 Reg 5 of the 2014 Amnesty Regulations.

30 Ackotia supra $\mathrm{n} 26$.

31 See the Minister's media statement 'Removal of adverse consumer credit information and information relating to paid up judgments' 2014-02-27 (available from http://www.thedti.gov.za, accessed 2014-09-01) (hereinafter the Minister's Media Statement). The statements were also confirmed by attorney, Stephen Logan who was also one of the drafters of the 2014 Amnesty Regulations, during his presentation entitled 'Factors that informed the removal of adverse credit information' at the DTI's Seminar on the Impact of the National Credit Act \& Affordability Assessment Regulations held in Pretoria on 2014-09-16 (hereinafter the DTI's September 2014 Seminar).

32 Ibid.

33 See the Minister's Media Statement supra n 31 
[T] he key pillars of the Act is the requirement for credit providers to conduct affordability tests before extending credit to consumers. The research we commissioned for the purposes of asses[s]ing the feasibility of removing adverse consumer credit information has revealed glaring gaps in how these tests are conducted by credit providers. In some instances these affordability tests are not conducted at all ...

Failure to conduct these affordability tests has results in reckless loans being extended to consumers that are already over-indebted, thus impacting on their ability to repay such loans ... Of primary concern also is the trend among credit providers to lazily use blacklisting at the credit bureau as the substitute for affordability test. It is not uncommon for a consumer to be declined credit purely on the credit bureau blacklisting without even conducting the affordability test (own emphasis).

Similar reasons were given to justify the creation of the Amendment Act, empowering the Minister to issue and prescribe Affordability Regulations which credit providers must comply with. It is the Minister's view that the self-regulatory method, allowing credit providers to determine for themselves their assessment modules and methods, did not yield positive results. ${ }^{34}$

According to the Minister, another major reason for the latest amnesty was that there were clear indications that the blacklisting of consumers at the credit bureaux had become a new impediment to employment opportunities. He added that: ${ }^{35}$

Having alluded to circumstances that led to consumers being blacklisted, it is a fact that adverse consumer credit information has been used incorrectly by some credit providers to deny consumers access to credit to secure homeloans, even where their financial position has changed. In terms of the regulations, a judgment would be reflected on the record of a consumer for five (5) years at the credit bureau, irrespective of the consumer having paid up. The process to remove such negative listing involves the court, which adds another cost to the consumer unnecessarily.

This Notice [that is, Regulations] provides a simple and quick process to remove such negative information without approaching the court once the consumer has paid up. It also provides relief to a consumer, whose financial position has changed to start on a clean slate and maintain a clean credit record going forward. While there is a chance that a few consumers that should not benefit from this Notice due to their repeat dishonest behaviour in regard to credit repayment, it would be easy to identify these consumers. Most consumers have however welcomed this second opportunity, and have committed to keep their credit record clean going forward. This Notice must benefit these most deserving consumers.

During a news conference in 2013, the DTI projected that only about 1,6 million consumers would benefit from the 2014 Amnesty Regulations. This figure was in contrast to the approximately 4 million consumers that the 
Credit Providers' Association and the Credit Bureau Association said would benefit from it. ${ }^{36}$

At this stage it is still too early to determine exactly how many consumers will benefit from the 2014 Amnesty Regulations. At the end of September 2013, credit bureaux held records for 20.29 million creditactive consumers, at the end of December 2013 the number increased to 20.64 million, and it increased further to 21.71 million at the end of March 2014. ${ }^{37}$ Consumers classified in good standing, stood at 10.71 million at the end of December 2013 and just a few months later the number miraculously increased to 12.11 million, despite there only being 1.07 million new records being added to the credit bureau. According to the NCR's Credit Bureau Monitor Quarterly Reports, the number of consumers with impaired records stood at 9.34 million at the end of December 2012 and exactly a year later, it had increased to 9.93 million. However, at the end of March 2014 the numbers of consumers with impaired records decreased to 9.60 million. ${ }^{38}$ These improved figures are the first to illustrate how many consumers were affected by the 2014 Amnesty Regulations. Unfortunately they only reflect the situation as at the end of March 2014. The executive manager, Ms Jeannine Naudé-Viljoen of the Credit Bureau Association, however, reported that during September 2014, around 5 million consumers had benefited. She added that credit bureaux removed credit information relating to 100000 paid up judgments and 13 million adverse classifications from their credit records. ${ }^{39}$ She did, however, point out that these numbers vary across credit bureaux depending on the market position of a specific bureau.

Over the years, there were a startling number of consumers that were struggling to remain up-to-date with their credit repayments pointing to the severity of over-indebtedness in South Africa. For instance, since the NCA's inception in June 2007, R14 billion was repaid to credit providers from consumers under debt review. ${ }^{40}$ However, the effect of the latest amnesty is that a distorted rosy picture is created that does not truly reflect the number of consumers who have bad debt repayment records and are currently over-indebted.

36 Brand-Jonker 'Vier miljoen mense se kredietrekords dalk gepoets' (available from http://www.sake24.com, accessed 2014-09-01).

37 See NCR's Credit Bureau Monitor (Fourth Quarter) (2013) 1 and NCR's Credit Bureau Monitor (First Quarter) (2014) 1 (both reports available from http:// www.ncr.org.za, accessed 2014-09-01).

38 Ibid

39 Statements made during her presentation entitled 'Perspectives on the removal of adverse credit information' at the DTI's September 2014 Seminar supra $\mathrm{n} 31$

40 See the presentation made by Mr Lesiba Mashapa, company secretary of the NCR, entitled 'Impact of the Credit Amendment Act, the removal of adverse credit information and affordability assessments' at the DTI's 2014 September Seminar supra n 31 
Credit providers, particularly banks, strongly opposed the introduction of the second amnesty. A primary concern was that the lack of access to adverse credit listings would lead to an increase in lending risks, as credit providers would be unable to distinguish between consumers who have received amnesty, although they are high-risk lenders, and consumers who are, factually, low-risk lenders who can manage their credit well. ${ }^{41}$

\section{Overview and Application of the 2014 Amnesty Regulations}

The 2014 Amnesty Regulations relate to the once-off removal of certain adverse consumer credit information from the credit records, including payment profiles, of all consumers, kept by all the registered credit bureaux $^{42}$ as at 1 April 2014. Regulation 1 provides that "adverse consumer credit information" for purposes of these regulations means:

(a) adverse classifications of consumer behaviour are subjective classifications of consumer behaviour and include classifications such as 'delinquent', 'default', 'slow paying', 'absconded' or 'not contactable';

(b) adverse classifications of enforcement action, which are classifications related to enforcement action taken by the credit provider, including classifications such as 'handed over for collection or recovery', 'legal action', or 'write-off';

(c) details and results of disputes lodged by consumers irrespective of the outcome of such disputes;

(d) adverse consumer credit information contained in the payment profile represented by means of any mark, symbol, sign or in any manner or form (own emphasis).

The 2014 Amnesty Regulations also provide for the once-off, as well as on-going, removal of information relating to "paid up judgments" of consumers. Regulation 1 defines "paid up judgments" as civil court judgment debts, including default judgments, where the consumer has settled the capital amount under the judgment. It is not clear what is meant by the term "capital amount" or exactly which amounts the term includes as neither the NCA nor any other regulation issued in terms of the Act, defines the term's precise meaning. The NCA refers to and defines only the term "principal debt". ${ }^{43}$ The 2014 Amnesty Regulations are also completely silent about the payment (settlement) of the interest component and any other costs (for example, legal costs) in connection with the judgment debt. From a literal reading of the definition, it seems that a consumer would only have to pay the outstanding capital amount if he wishes to benefit from the amnesty. Even if that is the intended

41 Ackotia supra $\mathrm{n} 26$

42 This refers to a credit bureau registered with the NCR in terms of s 43 of the NCA.

43 This means the amount calculated in accordance with s 101(1)(a) plus the value of any item listed in s 102 and is the amount deferred (as defined in reg 39(1) published in GN R489 in GG 28864 supra $\mathrm{n} 21$ in terms of the agreement (see s 1 of the NCA). 
meaning of the term, it should be remembered that the consumer is still liable for the payment of the interest, despite details regarding the "paid up judgment" being removed from his credit record. Also, a removal of the details of the judgment from the credit record does not automatically amount to a rescission of the judgment. ${ }^{44}$

The same problem did not arise under the 2006 Amnesty Regulations. In those regulations, regulation 3(3) provided that a consumer had to submit prima facie proof of the "full payment of the judgment debt" (own emphasis) if he wanted the qualifying paid up civil judgment (that is judgment for up to R50 000) to be removed from his credit record. But, in terms of the 2014 Amnesty Regulations, it is the credit provider that must submit the information regarding payment of the judgment debt. The 2014 Amnesty Regulations provide that the credit provider must submit the information relating to a paid up judgment to all registered credit bureaux within seven days of receipt of "such payment" (that is, the capital amount - set out in the definition of paid up judgment). ${ }^{45}$ However, it is unlikely that a credit provider will inform a credit bureau to remove details regarding a "paid up" judgment unless all the outstanding amounts, including interest and legal costs, have been settled. The NCA clearly states that it aims to encourage the fulfilment of financial obligations by consumers. ${ }^{46}$ The Act also clearly stresses that the mechanisms aimed at relieving the over-indebtedness of consumers are all based on the principle that consumers should satisfy "all responsible financial obligations". 47 Seen in this light, it is improbable that it is the intention of the legislature to provide for the consumer to only settle his capital amount before benefitting from the amnesty. ${ }^{48}$ It is probably just another case of ambiguous drafting for which the NCA has become notorious.

All registered credit bureaux had to remove the abovementioned adverse credit information and the "paid up judgment" data from their

44 Currently a project is underway in which attention is given to possibly amending the legislation dealing with the rescission and abandonment of judgments. Specific attention is given to how the Magistrates' Courts Act 32 of 1944 may be amended so that it allows for an easier, more efficient and cheaper method in which a judgment that has been settled by consumers may be rescinded or abandoned (see eg, the Working document Magistrates' Courts Amendment Bill 2013-02-21 (available from http:// www.rebels.co.za, accessed 2014-08-01) and Kelly-Louw supra n 5 at 3940).

45 Reg 3(a) of the 2014 Amnesty Regulations.

46 See ss 3(c) (i), (g) \& (i) of the NCA.

47 Ss $3(\mathrm{~g}) \&$ (i) of the NCA.

48 One of the drafters of the 2014 Amnesty Regulations recently said that it was not the intention to exclude the interest component, but rather to prohibit credit providers from piling "all kinds of extra costs onto the judgment debt" so that it could not be settled by a consumer. Unfortunately, the drafter did not elaborate on the type of costs he was referring to (see Logan 'Factors that informed the removal of adverse credit information' a presentation made at the DTI's September 2014 Seminar supra n 31). 
records within two months (that was before 1 June 2014) from the effective date (that is 1 April 2014). ${ }^{49}$ A credit bureau could have requested a seven day extension beyond this two month period. However, to have qualified for such an extension, the credit provider had to have applied for it at least seven days before the expiry of the two month period. ${ }^{50}$ A credit bureau also had to notify all the other registered credit bureaux within three days of any of the adverse and paid up judgment information being removed from its records. ${ }^{51}$ The credit bureau receiving such notifications, also had three days to remove similar information from its records. ${ }^{52}$ A credit bureau is also not permitted to record or retain on its register, any of the information that was removed in terms of these regulations. ${ }^{53}$

As already mentioned, provision is made for credit bureaux to remove information regarding paid up judgments on an on-going basis after the final "clean-up" deadline. ${ }^{54}$ A credit provider must submit all information relating to paid up judgments on a continuing basis to all registered credit bureaux within seven days of receipt of such payment from a consumer, ${ }^{55}$ and the credit bureaux must remove such information within seven days after receiving proof of such payments ${ }^{56}$ (note the concerns expressed above regarding the settlement of only the capital amount of judgments).

In general, credit providers had until the effective date of the regulations to submit the adverse and paid up judgment data to credit bureaux that had to be removed, but if they failed to do so by that date they could still have submitted the remaining data within seven days after the effective date. However, if they had failed to comply with this later deadline, they were no longer permitted to submit the adverse credit information to credit bureaux for listing. ${ }^{57}$

Regulation 3(d) provides that a credit provider is not permitted to use adverse consumer credit information and information relating to paid up judgments that have been removed in terms of the regulations for "any reason, including credit scoring and assessment" of consumers. A credit provider is also not permitted to re-submit, for purposes of listing,

49 Regs 2(a)-(b) of the 2014 Amnesty Regulations. During this two month period a credit bureau had to ensure that the adverse credit and paid up judgment information that ought to have been removed in terms of this amnesty regulations was not displayed or provided to credit provider or any other person requesting such information (reg $2(\mathrm{~h})$ ).

50 Regs 2(c)-(d) of the 2014 Amnesty Regulations.

51 Idem $2(\mathrm{e})$

$52 \operatorname{Idem} 2(\mathrm{f})$

53 Idem 2(g).

54 Idem 2(a)(ii).

55 Idem 3(a).

56 Idem 2(i)

57 Idem 3(b)-(c). 
adverse and paid up judgments information that was removed, in terms of these regulations, to any credit bureau. ${ }^{58}$

The 2014 Amnesty Regulations also imposed various reporting duties on credit bureaux and stipulated that an audited report containing certain information had to be submitted to the NCR one month after the deadline that was set for removing the adverse credit and paid up data (that was due at the beginning of July 2014). ${ }^{59}$ Within three months after receiving the reports from the credit bureaux, the NCR has to submit a report to the Minister on the effectiveness and compliance with the regulation (due at the beginning of October 2014). So although the NCR's Credit Bureau Monitor Quarterly Report for March 2014 already contains some information reflecting what impact the removal of the data has had on the records of consumers, ${ }^{60}$ the full scope and impact of this credit amnesty on the industry is still unknown. The 2014 Amnesty Regulations also imposes a duty on the NCR to regularly monitor the implementation of these regulations and ensure that information related to paid up judgments is removed continually. ${ }^{61}$

Any non-compliance with the 2014 Amnesty Regulations will be dealt with in terms of the remedies and procedures in the NCA. ${ }^{62}$ Therefore, a credit bureau or a credit provider may even be deregistered by the NCR for failing to adhere to these regulations.

The 2014 Amnesty Regulations affect the credit bureau reports of a consumer, who is a natural person, stokvel or a specific type of trust ${ }^{63}$ and who is a party to a credit agreement to which the NCA applies. There is nothing in these regulations to prevent the 2014 Amnesty Regulations from also applying to the credit bureau reports of a juristic person who qualifies as a consumer and who is also a party to a credit agreement in respect of which certain parts of the NCA applies. ${ }^{64}$ There is also nothing in the NCA itself that states that the provisions in the Act ${ }^{65}$ dealing with consumer credit information do not or could not also apply to juristic persons. ${ }^{66}$ Although it can probably be argued that section $70(1)$ of the

$58 \operatorname{Idem} 3(\mathrm{e})$

59 Idem 4(a)

60 See the discussion in par 21 supra.

61 Reg 4(b) of the 2014 Amnesty Regulations.

62 Idem 7

$63 \mathrm{~S} 1$ of the NCA provides that a juristic person includes a partnership, association or other body of persons (corporate or unincorporated), or a trust if there are three or more individual trustees; or the trust is itself a juristic person. The section excludes stokvels (as defined in $\mathrm{s} 1$ ) from the definition of a juristic person, and therefore stokvels enjoy the full protection of the Act just as natural persons do when they borrow money from third parties, such as banks or micro-lenders. Certain trusts (for example, where there are fewer than three individual trustees) will also qualify as natural persons.

64 For a full discussion of the NCA's limited application to juristic persons, see Kelly-Louw Consumer Credit Regulation supra n 6 at par 2.3.1.

65 See ss $70 \& 72-74$

66 See also s 4 read with s 6. 
NCA, that defines "consumer credit information", refers more to the information concerning natural persons than to juristic persons. ${ }^{67}$ In principle, however, the 2014 Amnesty Regulations apply also to the credit records of certain juristic persons held by credit bureaux. Practically, this is neither here nor there as credit bureaux apparently either don't keep credit reports of juristic persons or have very limited credit information on juristic persons. ${ }^{68}$ Apparently this situation will only change if it becomes compulsory for credit bureaux to also keep the records of juristic persons. ${ }^{69}$

\section{Credit Information Retained in the Credit Reports, Despite the Application of the 2014 Amnesty Regulations}

The 2014 Amnesty Regulations do not entail (nor should they be so interpreted) that a consumer's debt repayment history should be totally destroyed. ${ }^{70}$ Credit bureaux are still required (and allowed) to maintain a record of a consumer's monthly payments and his payment profile. $^{71}$ The 2014 Amnesty Regulations simply remove certain adverse credit information and information relating to paid up judgments from a consumer's credit bureau report so that they are no longer reflected therein.

The NCA is prescriptive of the type of consumer credit information which may be held by a credit bureau. Section 70(1) provides that consumer credit information is information concerning a consumer's (person's):

- credit history, including his applications for credit, his concluded credit agreements (current and previous), pattern of payment or default under any credit agreements, debt re-arrangement/restructuring in terms of the NCA, incidence of enforcement actions with respect to any credit agreement, the circumstances of termination of any credit agreement, and related matters;

- financial history (such as his past and current income, assets and debts and other matters within the scope of the consumer's financial means, prospects and obligations); ${ }^{72}$

- education, employment, career, professional or business history; or

- identity, including his name, date of birth, identity number, marital status, past and current addresses and contact details.

67 See the discussion of s 70(1) in par 3 infra.

68 A statement made by Naudé-Viljoen during her presentation entitled 'Perspectives on the removal of adverse credit information' at the DTI's September 2014 Seminar supra $n 31$.

69 Ibid.

70 See the Minister's Media Statement supra n 31.

71 Ackotia supra n 26.

72 As defined in s 78(3) 
Generally, a credit report compiled by a credit bureau includes the abovementioned information. It should be remembered that credit bureaux keep negative as well as positive information on a consumer. The report also contains a payment profile. The payment profile refers to the consumer's history relating to a particular transaction ${ }^{73}$ (for example, the payment of instalments in terms of a mortgage agreement). The payment profile generally includes a record that indicates by way of numerals, the number of months that it has taken a consumer to pay off a specific debt. Sometimes a range of numbers, for example zero to five or more, is used to reflect this. The payment profile also indicates if a payment (instalment) for a particular month was missed. The payment profile normally also includes a categorisation, reflected by an abbreviation or code, and follows from the assessment of the payment profile and indicates whether the consumer is a punctual payer, slow payer or defaulter, and whether any debts of the consumer have been written off, any legal action (for example judgment) has been taken and if so, whether and when the judgment debts were settled.

The listing of the number of months it takes a consumer to repay his debt listed in his payment profile, is a factor that a credit bureau takes into consideration when it creates a credit score band (credit score) for a specific consumer. Credit reports normally set out the credit score bands that classify (rate) the likelihood of a particular consumer defaulting on his debt. A report indicates in which category a particular consumer falls, for example if he carries a minimum, low, average, high or very low risk for possible default. The credit score is based on the consumer's full credit profile and is usually the score that a credit provider uses when deciding whether to grant credit or extend credit to a consumer. Every credit bureau uses its own methods and numerals to determine the credit score band of a particular consumer. Therefore, the score band is not always the same for a consumer at the respective credit bureaux. Unfortunately there is no consistency in the methods used by the respective credit bureaux in South Africa to calculate the credit score band of consumers, and it is not always known how they derived at a particular score band for a specific consumer. It is, however, important to note that a credit bureau does not decide whether any credit should be granted, it generally just indicates what the possible risk factor for default by a consumer is, and such determination is not an exact science.

Upon a reading of the definition of "adverse consumer credit information" set out in the 2014 Amnesty Regulations, it becomes unclear how they precisely affect the payment profile of a consumer. For instance, may a credit report still contain a payment profile? If so, may the credit report still include the numeric content (for example, number of months it takes to repay a debt) as explained above or does regulation 1 prohibit this? Further, may the report reflect any missed payments (instalments) for a specific debt?

73 As defined in reg 17(5) published in GN R489 in GG 28864 supra $\mathrm{n} 21$. 
From the definition of "adverse consumer credit information" set out in regulation 1 (quoted above), ${ }^{74}$ it is clear that there are three major categories of information. That is, information concerning:

- Adverse classifications of consumer behaviour; ${ }^{75}$

- Adverse classifications of enforcement action; ${ }^{76}$ and

- The details and results of disputes lodged by consumers. ${ }^{77}$

Regulation 1(a) deals with adverse classifications of consumer behaviour and defines them as subjective consumer behaviour and provides a few examples that would constitute that description. The regulation lists classifications such as "delinquent", "default", "slow paying", "absconded" or "not contactable" as subjective examples. The list is not exhaustive and can, therefore, include any other classification which is also based on a person's subjective opinion. The regulation is completely silent about the reporting of any objective classification in this regard. "Subjective" is defined as "one's own feeling or capacities rather than being actually existent". 78 "Something that is subjective is strongly influenced by personal opinions and feelings". 79 In other words, if a person makes a subjective classification, he would be referring to his own view or feeling that is not impartial and not necessarily based on actual facts. In contrast, an "objective" opinion indicates "outward things, exhibiting actual facts uncoloured by exhibitor's feelings or opinions". 80 Therefore, if a person makes an objective classification, he would be fair and state his opinion based on a fact, rather than on personal feelings. ${ }^{81}$ It should however, be pointed out that some of the examples given in regulation 1 (a) as being subjective classifications, could easily also constitute examples of objective classifications. However, be that as it may, as these examples have specifically been listed as examples of subjective classifications, one will not easily succeed in arguing that they are actually objective classifications or at the very least can also be.

The scope of regulation 1 (b) is more straightforward. This regulation concerns all classifications concerning the enforcement action taken against a consumer - right from the beginning that legal action is taken (for example, where the matter is handed over for collection), to the end of such legal action when the debt is written-off. This regulation does not distinguish between objective or subjective classification being made in this regard.

The ambit of regulation 1 (c) is also clear and does not require any further interpretation or analyses.

\footnotetext{
74 See par 22 supra.

75 Regulation 1(a) of the 2014 Amnesty Regulations.

76 Idem $1(\mathrm{~b})$.

77 Idem 1 (c).

78 See the Concise Oxford Dictionary (1976) 1148

79 See Cobuild Essential English Dictionary (1988) 798.

80 See the Concise Oxford Dictionary supra n 78 at 752

81 See Cobuild supra n 79 at 540.
} 
Unfortunately, the same cannot be said of the interpretation of regulation $1(d)$. Regulation $1(d)$ is rather confusing. It does not seem to introduce a further category of consumer credit information. Regulation 1 (d) does not give a description or provide any example of what adverse consumer credit information it specifically refers to. The sub-regulation, rather, seems to repeat the generalised phrase "adverse consumer credit information" which has been fully set out and explained in regulations 1 (a)-(c). Therefore, sub-regulation (d) seems to simply refer to the three major categories of adverse consumer credit information set out in regulations $1(\mathrm{a})-(\mathrm{c})$. It appears that what regulation $1(\mathrm{~d})$ attempts to say, is that any of the qualifying adverse information listed in regulations 1 (a)-(c), which were represented or reflected in the payment profile by way of a mark, symbol, sign or in any manner or form, must be removed in terms of the 2014 Amnesty Regulations. Therefore, any of the adverse information set out in regulation 1 (a)-(c) was relevant in credit bureaux determining whether they had to amend the payment profile of a specific consumer and whether any adverse information reflected by any mark, symbol, sign or any other method had to be removed from a specific payment profile. In other words, all the adverse information that fitted either of the three descriptions in regulations 1(a)-(c) and was reflected in the payment profile in the form of a mark, sign (for example, by an asterisk) or in any other way and that was on the profile as at the effective date, had to be removed in terms of the amnesty regulations.

It, therefore, follows that the 2014 Amnesty Regulations did not affect the objective classification of consumer behaviour in a consumer's payment profile. An interpretation that these regulations aim to completely remove the payment profile of consumers would go against the very object of the NCA, and the statutory duty the Act imposes on credit providers to assess the debt repayment histories of consumers before granting or extending credit. The Affordability Regulations also stress the important role that credit bureau reports play in assisting a credit provider to properly conduct pre-agreement credit assessments of consumers. It is, therefore, highly unlikely that the 2014 Amnesty Regulations aim to remove the payment profiles of consumers.

The fact that regulation $1(d)$ makes reference to a payment profile also strengthens the reasoning that the regulations do not aim to remove payment profiles contained in credit bureau reports. All that the regulations do, is remove adverse credit information that meets certain criteria from the payment profile. If the regulations intended to remove payment profiles completely, they would clearly have stated so, and there would have been no need for regulation $1(\mathrm{~d})$ to deal with the removal of certain adverse listings reflected in payment profiles. Regulation $1(\mathrm{~d})$ undoubtedly provides for the continuation of payment profiles. This interpretation is also strengthened by the Minister's statement that: "The payment profile of a consumer will remain available for credit providers to help assess the risk in extending credit to consumers. This obviously being one of the many factors considered by 
the credit provider before extending credit". 82

A pertinent question that then arises, is whether the payment profile can still include the information regarding the number of months it has taken a consumer to repay a specific debt? The answer to this question depends on whether this kind of reporting is considered to be a subjective classification of consumer behaviour or rather an objective classification. Simply stating the number of months that a consumer has taken to repay a specific debt would in my view constitute an objective classification. Such a statement merely provides a historical history of payment (a fact, if you will). However, certain subjective views can be drawn by credit providers assessing such information, such as the fact that a consumer is a slow payer. The possibility that such deductions may be made from the information does not necessarily mean that the objective history of repayment is changed into a subjective classification. This type of information remains an objective classification of consumer behaviour. In terms of the 2014 Amnesty Regulations, it would therefore seem to be permissible if the payment profile contains information reflecting the number of months it took a consumer to repay a debt. The payment profile may, however, also not contain any of the adverse consumer information (including subjective classifications of consumer behaviour) reflected by an abbreviation, sign, mark, or code and indicating that the consumer is a slow payer or defaulter, that certain debts have been written-off or any legal action has been taken, and if so, whether and when the judgment debts were settled that had to be removed in terms of the credit amnesty regulations. Payment profiles issued post-amnesty may still include the coded categorisations which may include a subjective interpretation of the numeric profile of a consumer. ${ }^{83}$

It would, therefore, seem that a credit provider may still use a consumer's payment profile reflecting objective information and his credit score band allocated by a credit bureau in conducting its statutory assessment of the affordability of the consumer. Even though certain listed adverse consumer credit information was removed from the existing records kept by the credit bureaux, the credit score bands and the payment profile reflected in the credit bureau report, will still reflect certain behavioural trends of the consumer that a credit provider will be able to use as a tool in assessing the probability of poor repayment by a specific consumer.

82 See the Minister's Media Statement supra $n 31$

83 Similar views were expressed during a radio talk show hosted on the Unisa Radio 'Credit Amnesty - What this really means for consumers' on 2014-05-19 by Mr Lesiba Mashapa, company secretary of the NCR and Mr Nicky Lala-Mohan, company secretary of the Banking Association of South Africa. 


\section{The Automatic and On-going Removal of Adverse Information in terms of the National Credit Act}

The Amendment Act inserted a process into the NCA whereby certain adverse consumer credit information may be removed automatically from the credit record of a consumer kept by all registered credit bureaux on an on-going basis. ${ }^{84}$ The Amendment Act includes section $71 \mathrm{~A}$ into the NCA and provides as follows:

$71 \mathrm{~A}$. (1) The credit provider must submit to all registered credit bureaux within seven days after settlement by a consumer of any obligation under any credit agreement, information regarding such settlement where an obligation under such credit agreement was the subject of -

(a) an adverse classification of consumer behaviour;

(b) an adverse classification enforcement action against a consumer;

(c) an adverse listing recorded in the payment profile of the consumer; or

(d) a judgement debt.

(2) The credit bureau must remove any adverse listing contemplated in subsection (1) within seven days after receipt of such information from the credit provider.

(3) If the credit provider fails to submit information regarding a settlement as contemplated in subsection (1), a consumer may lodge a complaint against such credit provider with the National Credit Regulator.

(4) For the purpose if this section-

(a) 'adverse classification of consumer behaviour' means classification relating to consumer behaviour and includes a classification such as 'delinquent', 'default', 'slow paying', 'absconded', or 'not contactable'; and

(b) 'adverse classification of enforcement action' means classification relating to enforcement action taken by the credit provider, including a classification such as 'handed over for collection or recovery', 'legal action' or 'write-off' (own emphasis).

The section provides for the removal of certain adverse information "after settlement by a consumer of any obligation under any credit agreement", but what exactly these words entail are uncertain. The meaning of the word "settlement" is also unclear. For instance, do these words refer to a consumer having to pay only the outstanding "capital amount" in terms of the amount in arrears, which form the subjectmatter of the adverse information, or do they also refer to him paying all his arrears plus the relevant interest (including mora interest)? Or, do they simply refer to a consumer paying, for example, the missed instalments (and the interest included therein) in terms of an instalment agreement? No guidance is found in either the Amendment Act or the

84 See s 71A inserted into the NCA by the Amendment Act. 
2015 Regulations. Regulation 19(10) of the 2015 Regulations simply provide that "upon settlement of the amount in arrears, which form the subject matter of the adverse information, the source of the data [for example credit provider] must in its next data of submission to the credit bureaus, advise such credit bureaus that the arrear amounts have been settled". Furthermore, regulation 19(11) of the 2015 Regulations also stipulates that the listing of a civil court judgment and administration order must be removed from the credit bureau records of a consumer where the source of the data (for example credit provider) advises a credit bureau that the capital amount, due in terms of either of them, have been settled (note earlier concerns expressed above ${ }^{85}$ regarding the meaning of the term "capital amount"). It should be noted that it is common practice for credit agreements to contain clauses providing for the acceleration of payments (instalments) in the event of a consumer's default, thereby making the full outstanding debt in terms of the credit agreement immediately payable. In such cases, it will be unclear what exactly the consumer must "settle" for the adverse information to be removed in terms of section $71 \mathrm{~A}$.

Section $71 \mathrm{~A}$ does not distinguish between objective or subjective adverse classifications and listings. The 2014 Amnesty Regulations make specific reference to adverse classifications of consumer behaviour which are subjective, but in section $71 \mathrm{~A}$ no such distinction is made. It is imperative that the objective listings remain in the payment profile, for example if a payment was missed for a month or the number of months it took a consumer to repay a debt, to enable a credit provider to conduct proper affordability assessment of consumers. However, from a literal interpretation of section $71 \mathrm{~A}$, it seems that the section aims to cater for the automatic removal of both types of information from the credit records as well as from the payment profile of a consumer, where the consumer settles his obligation which forms the subject-matter of the adverse information.

\section{A Few Closing Comments}

The NCA, in its current form, places a duty on a credit provider to take reasonable steps to assess the consumer's debt repayment history, but fails to stipulate what these reasonable steps are or which documents and records a credit provider may use during its assessment. Section 82(1), as amended by the Amendment Act, still gives a credit provider some leeway to create its own evaluative mechanisms or models and procedures to be used in meeting its assessment obligation under section 81. Therefore, one way in which a credit provider may conduct this assessment is for it to consult its own internal records it keeps on a consumer. Another is to obtain a credit report on the consumer from a registered credit bureau. In the Affordability Regulations, great emphasis is placed on the important role that credit bureau reports of consumers

85 See par 22 supra. 
play in credit providers conducting proper affordability assessments. For this to prove successful though, it is vital that the credit reports received from credit bureaux are reliable and complete.

Regulation 3(d) of the 2014 Amnesty Regulations provides that a credit provider is not permitted to use adverse consumer credit information and information relating to paid up judgments, that have been removed in terms of these regulations, for "any reason, including credit scoring and assessment" of consumers. It is, however, uncertain, if this removed adverse information may still be used by a credit provider to conduct the statutory assessment of a consumer where it obtained such information not from any credit bureau report, but from its own internal credit records for a specific consumer (for example where a consumer is an existing customer). It would not make sense to impose a statutory duty on the credit provider to assess the debt repayment history of a consumer, but to also simultaneously prohibit it from consulting its own internal records to do so. It will surely amount to gross reckless lending if a credit provider simply grants credit to one of its existing customers without first consulting its own records to determine the customer's repayment history with the credit provider. The only interpretation of regulation $3(d)$ that would make sense is that it simply forbids a credit provider to use the information "that ha[s] been removed in terms of these regulations" and was obtained specifically from a credit bureau. The 2014 Amnesty Regulations do not provide for the removal of qualifying adverse credit information which the credit provider keeps in its own internal records and was collected over time by the credit provider itself. It would not make sense if the regulations required a credit provider to turn a blind eye to their own adverse credit information concerning one of its existing customers. The regulations censor only certain information which the credit provider receives from credit bureaux, and not the information that the credit provider obtains from its own internal records. The court in Horwood $v$ FirstRand Bank Ltd ${ }^{86}$ clearly alluded to the fact that a different level of assessment was required from a credit provider when it conducts an affordability assessment for an existing customer as compared to when doing so for a new customer. Although a credit provider is thus permitted to use the adverse credit information it has obtained from its own records, regulation $3(\mathrm{e})$ clearly prohibits a credit provider from resubmitting such old information (ie the adverse information and paid up information that was removed in terms of the 2014 Amnesty regulations) to a credit bureau. This prevents a recycling of old information.

It also needs to be established whether a credit provider is permitted to ask a consumer, as part of the credit provider's affordability assessment of a consumer, any questions regarding the adverse credit information that was removed by the 2014 Amnesty Regulations or in terms of section $71 \mathrm{~A}$. For instance, is a credit provider allowed to ask a consumer if a judgment has ever been taken against him, although it was

86 Supran 6. 
subsequently settled and removed from his credit bureau record? Neither the 2014 Amnesty Regulations nor section 71A deals with this aspect; in principle, there is legally nothing that would prohibit a credit provider from asking this and similar questions. That being said, it is unlikely that it was the objective of the 2014 Amnesty Regulations (and by implication also of section $71 \mathrm{~A}$ ) to allow for this type of conduct as it severely diminishes the effect of the regulations.

It is also unclear from the wording in regulation 3(d) whether a credit provider may use any of the removed credit information for another purpose not relating specifically to the assessment of a consumer for instance as part of a credit provider's prudential and statutory reporting, compliance or auditing duties to a regulatory authority. A bank for example, is obliged in terms of Basel II (or the Second Basel Accord) and III (or the Third Basel Accord) to report certain information regarding its consumer's debts so that the information may be used in assessing the bank's risk profile so that adequate provision may be made for the bank's capital requirements. It is unlikely that the 2014 Amnesty Regulations aim to prevent credit providers from complying with such duties. It is also unlikely that the Minister even has this authority (or the power to issue such regulations) to interfere with the prudential and statutory reporting, compliance or auditing duties that do not specifically involve the NCR or the NCA. Regulation 3(d) must also be read with the objectives and the exact scope of the NCA. The NCA and its regulations aim to regulate consumer credit aspects, they do not regulate other regulatory issues of credit providers falling beyond their scope. A regulation issued in terms of the NCA can, in any event, never override a statutory duty placed on a credit provider by another piece of legislation, such as by the Banks Act. ${ }^{87}$ In the event of a conflict, the different purposes of each piece of legislation will have to be weighed against each other to find solution.

There are a few positive attributes of the 2014 Amnesty Regulations. In the first place, they definitely improve the prospects of benefiting consumers to obtain employment and successfully conclude rental agreements for properties. In general, landlords are hesitant (and often for good reason) to rent to blacklisted tenants. A consumer who was blacklisted due to circumstances beyond his control (for example because he lost his job or was experiencing temporary financial difficulty), should not be unduly punished for that. If such a consumer's financial position has subsequently improved, placing him in a position where he can afford the rental payments, a blacklisting should not prohibit him from being able to secure a rental property. Given the 2014 Amnesty Regulations, it would be wise for a landlord to also conduct a type of "affordability assessment" before concluding the lease agreement in order to protect its own interest. Secondly, the 2014 Amnesty Regulations compel credit providers to actually perform affordability assessments, preventing them from purely relying on credit bureau

87 Act 94 of 1990. 
reports, in making their decisions to grant credit. Lastly, it greatly minimises the costs for consumers to remove the information regarding paid up judgments from their credit records.

However, one enormous disadvantage of the credit amnesty is that a credit provider (and a potential landlord) no longer has the benefit of viewing adverse credit classifications and listings of a consumer made by other credit providers to determine the possible risk of default by the consumer. The credit provider is only able to rely on such adverse credit information if it obtained knowledge of the information by consulting its own internal records for the consumer. Going forward, the reports of credit bureaux will only list adverse credit information reported postamnesty. Section 71A also has the effect that the reports will also only reflect information permitted by that section.

It is evident that many consumers benefited from the second amnesty and were removed from credit providers' blacklists. Immediately after the amnesty came into effect, banks were swamped with applications from consumers who benefited from the amnesty. ${ }^{88}$ A serious downfall of the amnesty, however, is that it is now very difficult for a credit provider to correctly assess the debt repayment history and to distinguish between good and bad borrowers. If a credit provider, during an assessment period, receives a "good" credit report for a prospective consumer, who it suspects to have benefited from the latest amnesty, it is likely that the credit provider will grant the credit only at a very high interest rate to accommodate for the possibility of non-payment. ${ }^{89}$ If there is any doubt as to a consumer's debt repayment history and classification, the credit provider will classify the consumer as "bad". Receiving less credit information on a consumer poses a higher risk for a lender and usually results in higher credit costs for the consumer.

At first glance, it seems that the 2014 Amnesty Regulations are undermining the aim of the NCA to encourage responsible lending and prevent reckless lending from taking place. The 2014 Amnesty Regulations make it more difficult for a credit provider to make a proper evaluation of a specific consumer's affordability as well as determining the consumer's risk for possible default. The NCR, however, argues that the latest amnesty does not amount to a blanket amnesty which will result in consumers obtaining more credit than they can afford to repay. The NCR states that the Affordability Regulations, together with the new adverse listing rules and regulations, will buffer the effect of consumers taking up more credit than they can afford and will assist in preventing reckless lending. ${ }^{90}$ This, however, remains to be seen as the 2015 Regulations negatively affect the reliability of particular credit information kept by credit bureaux. For instance, the 2015 Regulations

88 For authority see $n 86$ supra.

89 Ackotia supra $\mathrm{n} 26$.

90 Ibid. 
amends regulation $17(1)^{91}$ by reducing the periods that certain adverse consumer credit information may be displayed on a consumer's credit bureau record.

The Minister clearly stated that the 2014 Amnesty Regulations do not aim to remove "the obligation on consumers to re-pay debt owed by them to credit providers. Instead, it seeks to create the incentive for consumers to re-pay their debt better and timely". However, I fail to see how it provides a consumer with an incentive to pay, it in fact creates the opposite and creates a further breathing ground for potential nonpayment by consumers. Apparently, at least 74 percent of consumers who benefited from the first credit amnesty were in default again with their credit repayments. ${ }^{92}$ If this figure is correct, then there is a good chance that it may be many of the same consumers that have now also benefited from the second amnesty.

An interesting question that has been posed, is whether a credit provider will be able to have legal recourse (for example a claim for damages) against the Minister for unpaid credit that it has granted postamnesty, based on the ground that the Minister has removed a primary source of assessing credit risk from the credit profile of a consumer? ${ }^{93}$ Only time will tell what the full impact of the second amnesty will be on the consumer-credit industry and whether it will exacerbate reckless borrowing amongst consumers. One also wonders whether we can expect more credit-information amnesties in future.

91 See reg 17(1) as it was originally published in GN R489 in GG 28864 and subsequently amended by GN R 1209 in GG 29442 supra $n 21$.

92 Ackotia supra n 26. The Minister mentioned that about 48 percent of the 64 percent of consumers who were granted amnesty in 2007, were again blacklisted (see Minister's Media Statement supra n 31 ).

93 Ackotia supra n 26. 